\title{
Campaign of Devastation
}

Assessing Motives for the Russian Government's

1999-2000 Destruction of Chechnya

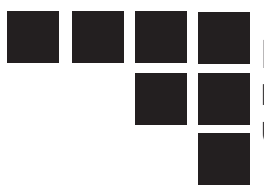

Laura Resnick

Bachelor of Arts, Political Science

University of Pennsylvania, 2014

In 1999, the Russian government all but razed Chechnya's capital city of Groznyy. The Russian military devastated Chechnya, killing thousands of civilians and wiping out vital infrastructure, signifying the capstone in a campaign of destruction inflicted on Chechnya to crush the burgeoning separatist movement. Government-rebel attacks like this one occur when governments seek to end insurgent campaigns by using force to kill rebels and destroy their base of support. ${ }^{1}$ The unusual paradox in the Russian-Chechen conflict was that the Russian government's ultimate intent was to stop the Chechen separatist movement and re-absorb Chechnya into the Russian Federation, and yet the damage it chose to inflict on the region was unimaginable in its scope and extent. Why would a government, in effect, completely destroy its own land and ruin what it considers its own infrastructure and part of its economy? Why would a government want to inflict massive pain, suffering and death upon enormous numbers of civilians that it considers to be legitimate members of its own nation? At face value, nothing appears more ludicrous than a government murdering its own civilians and scorching its own earth. This paper endeavors to prove, however, that such brutality was not paradoxical, but had underlying normative and strategic value for the Russian government.

\section{Hypotheses}

Why would the government harm its own land in an exceptionally brutal manner? At face value, this seems to be a counterproductive course of action. I postulate, however, that the Russian government's actions during the Chechen conflict were not paradoxical or counterproductive at all, but instead laden with normative and strategic value. I propose the following as the overriding motivation for the Russian government's use of overwhelming force in Chechnya, as exemplified by the 19992000 offensive:

H1: The Russian government used the violence in Chechnya as a means of signaling its strength to other actors in the Russian Federation who may have been considering secession. It also wanted to signal its strength to external actors. Additionally, Vladimir Putin took advantage of the situation in Chechnya to bolster his domestic political image.
I argue that the Russian campaign of destruction in Chechnya was considered a vehicle for messages about the power of the state and was used to threaten future rebellions with brutal retaliation. Russia had just emerged from the Cold War when it decided to initiate the first Chechen War; this campaign appears to be a move to not only restore its international reputation as a powerful state but also deter groups that wanted to push for secession from the Russian Federation. ${ }^{2}$ The second Chechen offensive, the subject of this paper, was also initiated during a period of internal political change. The domestic political events that influenced the government's decision to engage in the 1999-2000 offensive are discussed in this paper.

In addition to the normative argument, I propose two other hypotheses focusing on the strategic aspect of the violence:

H2: The use of overwhelming force in Chechnya was an attempt by the Russian government to coerce the rebels to 
cease fighting in order to prevent further destruction of their territory. It was also an attempt to undermine civilian support for the rebels by severely impacting the Chechen civilians' quality of life and endangering their persons.

Civilian life in Chechnya had certainly become unbearable by 1999.3 The Russian government was using overwhelming violence to literally crush the rebellion, but also to undermine support vital to its continuation as an insurgent movement.

\section{H3: The Russian government} bombarded the city of Groznyy and other areas within Chechnya so as to render the territory devastated, and to reduce the rebel's incentive to secede.

If the government succeeded in destroying vital infrastructure, ruining agricultural sites, and destroying cities and major economic centers, the rebels would face a difficult period of reconstruction in the event of a successful secession. Such devastation could deter secession entirely or provide a safeguard if secession were successful, in that the state may be able to re-establish economic and social control of the newly independent region in the period of intensive reconstruction when the new state is weak and reliant on external aid. The Russian government therefore had a strategic interest in destroying Chechnya: while the government was hurting its own territory, it was in effect trying to destroy its own land in order to retain it.

\section{Brief Overview of the Conflict in Chechnya ${ }^{4}$}

The Russian-Chechen conflict grew out of the breakup of the Soviet Union. During the Soviet era, Chechnya had been an autonomous republic in the USSR; after the fall of the Soviet Union, however, the Chechens fought their absorption into the Russian Federation and declared themselves the Chechen Republic of Ichkeria. Russian forces fought to put down the separatist movement in two phases, the first from 1994 to 1996 and the second from 1999 to 2007. During the first phase of the conflict, President Boris Yeltsin headed the Russian government. During the second phase, the government was lead by President Vladimir Putin, who was acting Prime Minister after Yeltsin's 1999 resignation and won the presidency in 2000.

In response to demands for autonomy among the Chechen people, elections were held in Chechnya in 1991. Dzhokhar Dudayev was elected president, although the elections were not recognized by the Russian Federation. Dudayev's supporters seized territory in the capital, Groznyy, and for the next three years refused the Russian Federation's offers for taking on the status of Republic within the

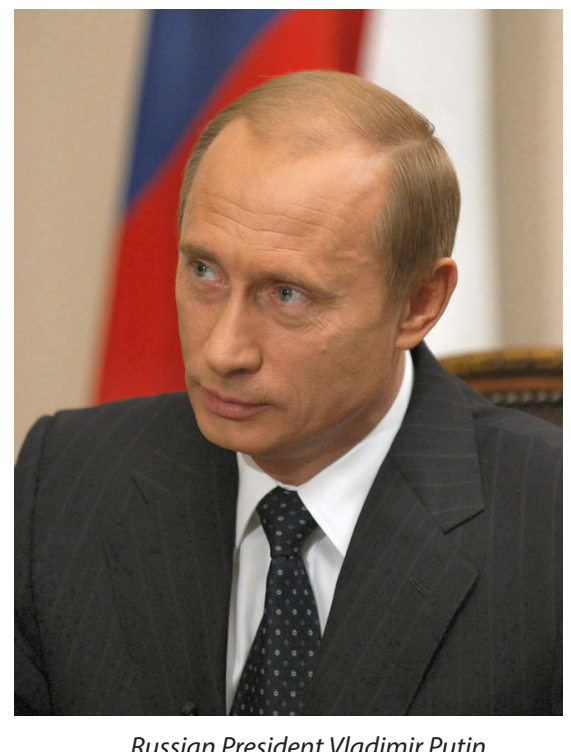

Federation. In 1994, Russian military forces launched the first full-scale military invasion into Chechnya, beginning the Russian-Chechen war in an attempt to crush the rebel movement. The first phase of the war was largely considered unsuccessful for the Russians.

The conflict was marked from the beginning by extreme and widespread violence against civilian areas and populations on the part of the Russian army. The destruction of the capital city Groznyy and countless other cities and villages in Chechnya destroyed much of Chechnya's infrastructure and in many cases 
reduced areas of the country to rubble. ${ }^{5}$ The best estimates state that through 12 years of active conflict, about 17,600 people were killed, with 17,500 to 33,393 deaths falling under the possible range. ${ }^{6}$

\section{Details of the 1999-2000 Russian Offensive}

The second Chechen offensive began in September 1999 and continued until the spring of 2000. It was marked by "artillery and air strikes on populated places" and intense destruction, especially in the capital city of Groznyy.

The US Country Report on Human Rights Practices for Russia notes that "in September and early October, government forces launched air and artillery attacks against numerous Chechen villages along the republic's eastern border with Dagestan," and "attempts by government forces to gain control over Chechnya's capital, Groznyy, were characterized by indiscriminate use of air power and artillery, which destroyed

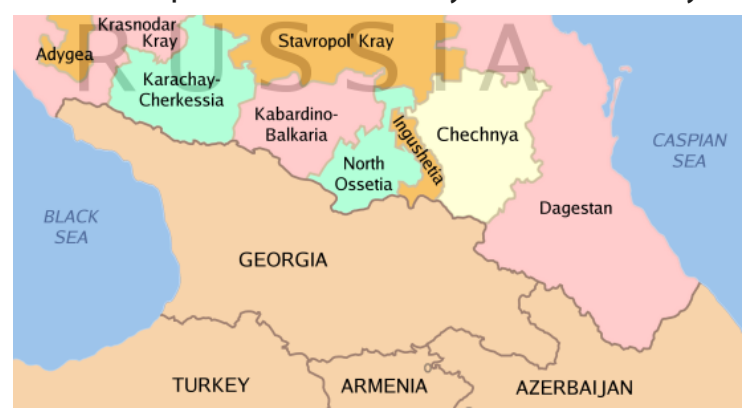

Chechnya and the Caucasus region

numerous residential and civilian buildings." The report relayed ICRC estimates of two-thirds of the 150,000 civilians in Groznyy fleeing the capital as a result of the Russian offensive. ${ }^{8}$ On October 27, 1999 the heaviest bombardment yet occurred within in the second phase of the conflict, resulting in 116 deaths from the Russian bombings. ${ }^{9}$ The Russian news agency Interfax reported that from October 27 - October 28 alone, the Russian air forces flew 150 sorties over Chechnya. ${ }^{10}$ While the Russian government claimed to use high-precision weapons, reports indicate that they in fact relied mainly on unguided missiles, which were not precise enough to guard against unnecessary civilian casualties. ${ }^{11}$
The US Country Report on Human Rights Practices for the year 2000 reported on the results of the campaign, indicating that:

Therewere some reports that federal troops purposefully targeted some infrastructure essential to the survival of the civilian population, such as water facilities or hospitals. The indiscriminate use of force by federal troops resulted in massive destruction of housing and commercial and administrative buildings, as well as the breakdown of gas- and water-supply facilities and other types of infrastructure. ${ }^{12}$

This is evidence that the Russian campaign of 1999-2000 was not only costly in terms of lives lost but also in terms of the amount of devastation wrought on regional infrastructure. As journalist Anna Politkovskaya would later note, the Russian government indeed succeeded in turning Chechnya into "a small corner of Hell."

\section{Russian Devastation of Chechnya as a Normative Mechanism - Signaling Power to Internal and External Actors}

With basic historical background of the conflict established, it is possible to examine the government's potential motives for such brutality. It is clear from an examination of the circumstantial evidence surrounding the offensive, as well as a synthesis of the available primary sources, that the offensive in Chechnya was an attempt to signal Russian strength both to internal and external actors. It is also clear that Putin used the situation to bolster his own political reputation. This section describes the domestic political situation of Russia in late 1999 and its relationship to the decision to launch the offensive as a signal to internal and external actors.

Political Circumstances Surrounding the 1999 Offensive:

Newly appointed Prime Minister 
Vladimir Putin was responsible for launching the second Chechen offensive in August of 1999. Putin was operating under the widespread normative assumption in Russia that Yeltsin's first offensive had been a failure: Thornike Gordadze notes that "...Putin and the military swore not to repeat the mistakes of the first war and from the start pursued a strategy of massive daily aerial attacks followed by the advance of ground troops, disregarding the number of civilian casualties this would provoke."13 Russia was also reeling from the bombings of Moscow apartment buildings, supposedly carried out by Chechen terrorists in September 1999.14 Because Putin would be facing a competative presidential election in March of 2000, it is likely that he wanted to take action to enforce his hard-line stance against crime and back up his image as a no-nonsense politician who would work to keep the territorial integrity of Russia intact. ${ }^{15}$ According to Gordadze, "the outbreak of the second Chechen war in October 1999 came just at the right moment: it sidelined political debate over who would succeed Boris Yeltsin and consolidated the electoral rise of his prime minister, Vladimir Putin."16

\section{Domestic Political Environment and its Relation to Internal Signaling:}

Barbara Walter's work on reputation and civil war postulates that in separatist conflicts, the state has strong incentives to pay the costs associated with reputation building, like engaging in long, bloody, and expensive military endeavors, because it faces the prospect of repeated play. Russia, an ethnically heterogeneous state, was operating under the threat of what Walter deems repeated play Putin engaged in the Chechen offensive as a visible warning to other ethnic groups in Russia that threats of succession would be met with violence. Walter relays: "as one Russian political scientist aptly observed: 'the fighting in Chechnya was not just against the Chechen rebels, it was against movements all around."'17 As Monica Toft similarly posits, states face an impetus to keep their territory intact, because the breakup of a state's physical territory could spell its demise. ${ }^{18}$ The problem confronting Russia was that it believed that it potentially faced a series of separatist movements, and thus had incentive to brutally suppress the Chechen movement rather than offer political concessions. This is because the war itself would bolster Russia's - and Putin's - reputation for decisive and bloody action in the face of rebellion, and in their anticipated outcome, future rebels would choose to remain subservient to Moscow rather than take up arms, out of fear for how the Russian government would react. ${ }^{19}$

The available historical evidence backs this claim. In 1999, there was significant domestic political unrest in Russia. Putin could have realistically expected to face separatist challenges in several surrounding regions, and was also dealing with numerous ethnic and minority groups that were unhappy with their standing in the Russian Federation. The Karachay-Cherkessia region was experiencing large-scale, non-violent unrest from 19992001 regarding a disputed election, which the government may have feared could foster a potentially violent separatist movement. The Dagestan region was also in turmoil, with groups like the Lezgin demanding the creation of an ethnic state; although the region seemed willing to compromise on their most radical demands at the time, there was still the potential for a violent movement to arise. Moscow was also engaged in negotiations with Tartarstan to forestall secession during this time. ${ }^{20}$ The government was also likely still scarred by the dissolution of the Soviet Union in 1991 and the accompanying separatist movements that led to radical loss of territory.

Walter's argument also sheds light on Putin's personal motivations for pursuing the second Chechen offensive in a highly brutal manner. She posits that the longer a leader plans on holding office, the more likely he is to resist territorial challenges, because he can anticipate a greater number of challenges arising during his tenure. ${ }^{21}$ Putin likely hoped that he would hold the office of President for 
some time; his predecessor Yeltsin had held the position for eight years, and Russian politicians have historically had a relatively long span of influence and office holding within the government. ${ }^{22}$ Therefore, it was sensible for Putin to take costly action very early on in his political career, even before officially gaining office, in order to forestall rebellion during his assumedly impending presidency. As Benjamin Valentino notes, "an understanding of mass killing must begin with the specific goals and strategies of high political and military leaders...sometimes even individual leaders can play a decisive role in instigating and determining the course of the slaughter."23 It is likely that the brutal nature of the 1999-2000 Chechen offensive was driven in large part by Putin's dictates and his desire to forestall repeated play combined with his concern for his personal reputation in Russia's domestic political sphere.

The Russian and international media certainly spoke at length about how Chechnya was an important early test for Putin, and how his actions fit with his "tough-man" image. As Jamie Walker reported for The Australian on December 11, 1999:

Chechnya is as much about Putin's political ambitions as it is about cleaning up this troubled corner of the Caucasus. And as a political strategy, it has worked brilliantly. Earlier this year, he was attracting just 2 per cent of support in presidential polls. By the time Russian aircraft began pounding the Chechen rebels' strongholds in September, it was up to 14 per cent. In recent polls his numbers have trebled again, catapulting him into favoritism for the presidential elections... In Russia, if nowhere else, Putin's war is a popular one. The reasons for this are complicated, reflecting public nostalgia for the might and power of the old Soviet Union and exasperation with the lawlessness that spilled across the borders of Chechnya and arguably into the Russian heartland itself.

The campaign in Chechnya was Putin's introduction onto the world stage. Before the Chechen campaign, Putin was "a political nobody" with a "strictly limited future in Boris Yeltsin's Kremlin."24 Nikolai Ulyanov stated in the Russica Izvestia on August 11, 1999 that when Putin was named Acting Prime Minister, he had "to act quickly in order to demonstrate that the President [Yeltsin] has made the right choice." Ulyanov also stated that "the Kremlin expects Putin to demonstrate toughness to

\section{If the violence in Chechnya was indeed a ploy to bolster Putin's military image, it worked not only on a domestic scale, but on an international scale as well}

the nation" and that quick action in Chechnya could "confirm his reputation as a tough Prime Minister and enhance his authority in the military community."

Polling from the Levada Center, a Russian public-opinion collection agency, lends credibility to Putin's logic of using Chechnya as a signaling mechanism and reputation-enhancer. When polled in December 1999, 30 percent of respondents said that the Russian government should prevent the separation of Chechnya" by all possible means," with a further 16 percent saying that they were against the separation but could accept it. Only 20 percent of those surveyed said that they supported such a separation. When polled in July 2002, a staggering 67 percent of respondents reported that they felt Chechens only understood "the language of force" and would interpret attempts to negotiate as a sign of Russian weakness. To that end, in December 1999, 68 percent of respondents felt that it was necessary to continue military operations rather than enter into negotiations. The Russian people certainly supported the use of force in Chechnya and were opposed to a potential separation of the region, even after witnessing the 1999-2000 campaign of destruction. 
Therefore, on a domestic level, Putin had much to gain reputation-wise from a tough stance in Chechnya - he was a relative newcomer to the Russian political stage, facing an election for the presidency in just a few months, and attempting to disprove Russia's view of the President as a failure and a weak figure. Today, Putin's brutal and bloody strategy seems to have succeeded in bolstering his reputation, as he will now be entering his third term as president and $13^{\text {th }}$ year in the Kremlin. Putin also managed to contain many of the potential separatist movements, indicating that he succeeded in his goal of cultivating a reputation for decisive and brutal action.

The Offensive and the Russian Image on the International Stage:

If the violence in Chechnya was indeed a ploy to bolster Putin's military image, it worked not only on a domestic scale, but on an international scale as well. International leaders rushed to condemn the brutality; Celestine Bohlen reported for The New York Times on December 8, 1999 that "from Washington, President Clinton has warned Moscow that it will pay 'a heavy price' if it continues killing civilians." The same article also reported that "in Britain, Foreign Secretary Robin Cook said aid from the European Union to Russia would be reviewed... if the Russian military did not observe 'basic humanitarian norms."' The Agence France-Presse announced on December 14, 1999 that "UN High Commissioner for Human Rights Mary Robinson, speaking in Geneva, described the plight of Chechen civilians as 'unacceptable."' While these are words of condemnation, and thus damaging to Russia's reputation, they also signify the strong disproval of the offensive actions of the Russian military by international actors. Russia may have calculated that having a reputation for brutality in the international system was better than having no reputation at all, or a reputation for having lost the power it had held while it was the Soviet Union. While this judgment may have hurt Russia's international reputation and hearkened back to the killing of civilians under the Stalinist regime, it would have furthered Russia's domestic purpose by demonstrating that the Russian military was not only wiling to crush any separatist rebellion, but was also willing to do so in the face of international criticism. The Levada Center reported that in February 2001, 58 percent of Russian poll respondents said that they thought Russia had reason to fear NATO - this could imply that there was popular domestic support for the bolstering of Russia's reputation for ferocity in the face of military challenges. ${ }^{25} \mathrm{As}$ Chollet and Goldgeier note, "after Yeltsin stepped down from office at the end of 1999, the new president, Vladimir Putin, sought to reassert Russia's traditional place in world affairs as a country to be reckoned with."26 It remains to be seen if Russia will be resurgent, but there is no doubt that the international community recognizes that Russia is still in many ways a power to be reckoned with, and an actor prone to using violent force.

\section{Assessment of the Evidence:}

There is substantial evidence to support the claim that the Russian government used the violence in Chechnya as a "shock and awe strategy" to signal its strength to other actors in the Russian Federation that may have been considering secession. The conflict also made an impression on external actors and possibly gave the Russians back some of their reputation for ruthlessness that they had lost since the breakup of the Soviet Union. The 1999-2000 offensive was also able to build Putin's reputation as a tough leader, and contributed substantially to his election as President in March 2000. The devastation thus served three related normative purposes, and proved valuable to Russia.

\section{Russian Devastation of Chechnya as a Strategic Mechanism - Rebel Resolve and Civilian Support}

I argue that the main motivation behind the 1999-2000 offensive was its assumed precedent-setting value and reputational benefits. However, I posit the secondary consideration that the Russian government 
wanted to use a strategy of extreme force in order to crush the rebel movement and undermine civilian support for the rebel movement. While I place this hypothesis secondary to my main normative hypothesis, I nonetheless believe that it represents an important facet in the Russian government's choice to act in such a brutal manner.

Valentino notes that fighting a counterinsurgency campaign is in itself an incentive for mass killing and states, "... regimes seeking to defeat major guerrilla insurgencies may be drawn to strategies of mass killing" because of the nature of insurgencies. ${ }^{27}$ Putin was facing a largely guerilla-based campaign, with militant groups striking Russian targets. Because the civilian population was much more readily available than the insurgent force, Putin and the Russian government had an incentive to attempt to defeat the insurgency by killing off all of its support, since it was a logistically easier maneuver. ${ }^{28}$ Civilians were not able to hide, and most of them were defenseless against Russian bombing and shelling. As Valentino predicts, this strategy did in fact lead to mass killing of Chechen residents; the Chechen people were easy targets for a government with enough air power to carry on such warfare, and the Russian government likely felt that there was no viable military alternative that would preserve their vital interests. ${ }^{29}$

The Russian government's strategy was likely bolstered by various examples of how overwhelming force could effectively be used to crush an insurgency, or at least to win battles in a conflict. One example that the Russian government likely drew on was the Soviet invasion of Afghanistan in the 1980s. Valentino postulates that even though the Afghan strategy was not a complete success, the Russians probably decided that there lacked a viable alternative for the Chechen situation..$^{30}$ Jason Lyall's study of Russian troops' shelling and its impact on subsequent insurgent attacks surprisingly concluded that such massive violence actually reduced the number of insurgent attacks, rather than inspiring the rebels to attack more heavily. ${ }^{31}$ Therefore, the early devastation provided an incentive to continue that level of violence, because it appeared to be serving Russians' strategic interests.

There are instances of Russian leaders explicitly expressing their desire to use force to crush the insurgent movement. On October 27, 1999 , news reports relayed televised comments by Viktor Kazantsev, head of the federal forces in Chechnya, in which he stated, "taking Grozny is not the point, the aim is to free Chechen territory of the terrorist bands. They must realize they have just two options -- to lay down their arms or to be destroyed." ${ }^{\prime 2}$ Other Russian leaders also spoke out on the strategic purpose of the violence. Before the campaign's start, Putin himself expressed in earnest that the Russian military would "...deliver strikes against any place where gunmen are based [in Chechnya]... we will destroy the gunmen." ${ }^{13}$

Examining the alternative military strategies available, it is easy to see why the Russian government settled on a strategy based on artillery and air power. The first phase of the conflict was considered a loss for the Russians and was marked by especially poor performance in urban combat, especially in Groznyy. This was probably a factor in the Russian military's choice to use bombing and shelling as a means of attack - it could be carried out from far away, but it was necessarily more indiscriminate than using ground forces to take a city. As Michael Coffy posits, "the Russian military learned to use brute force in the second Chechen war because it did not have a military that was capable of conducting a modern 'bloodless' war." ${ }^{34}$ As was previously noted, the Russian military did not possess precision munitions, only more indiscriminate weapons, which placed limits on how much they could avoid targeting civilians. Since the Russian military had no other viable strategic options, they were left with little choice to how they would rout the insurgents if they wanted to minimize Russian casualties while ensuring a cease to the insurgency.

The stakes were high enough that the Russian military could not take any chances 
with the campaign - they risked terrorist strikes on their homeland, as well as the threat of the secession of other parts of the Russian Federation if the Chechen separatists were successful. Therefore, the Russian military possessed many strategic incentives to utilize a campaign of destruction. On a theoretical level, the nature of the enemy meant that the use of massive violence against civilians was likely. On a practical level, the Russian military may not have had the ability or resources to conduct the campaign in any other way, given the stakes of losing. It was better for them to raze Groznyy than to risk protecting Chechen civilians at the expense of the safety and territorial integrity of the homeland.

\section{Russian Devastation of Chechnya as a Strategic Mechanism - Deterring Secession}

The Russian military wanted, as its ultimate aim, to crush the separatist movement. They could have done this by wiping out the

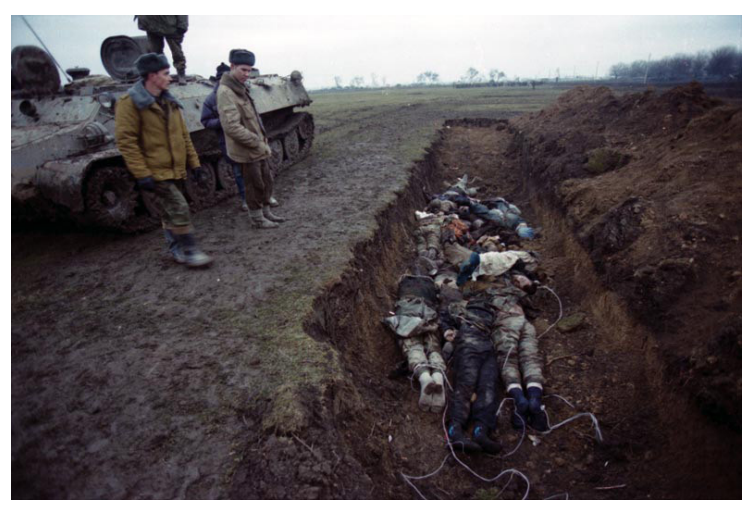

A mass grave in Chechnya

rebels, starving them of support, or convincing them to give up their struggle. One way of achieving the aim of convincing the rebels to surrender their cause could have been to render the territory so devastated that the rebels faced little incentive to secede.

Chechnya's destruction was so severe that repair of the region was likely inconceivable without financial support from the Russian central government. Chechnya was still reeling from the first phase of the conflict when the second phase commenced; a state budget had not existed since 1992, the collection of taxes had ceased and so Chechnya did not get its expected share of oil revenue, and in 1999 the region's oil output had dropped to 400 tons per day, compared to 4,200 tons in $1998 . .^{35}$ In 2002, the UN named Groznyy the "most destroyed city on the planet." ${ }^{16}$ Indeed, in 2000, the Russian government did pledge to provide support for Chechnya through the UN. ${ }^{37}$ Later, according to a January 29, 2001 news report by Agence FrancePresse, Russia provided \$514 million dollars worth of aid to Chechnya in 2001. In 2009, nine years after the Russian offensive, the Russian government was still pumping hundreds of millions of dollars into Chechen reconstruction. ${ }^{38}$ Had the separatists succeeded, it is unclear how they would have managed to rebuild without such funding, especially given that Chechen employment continued to be extraordinary - in 2009, Chechen unemployment levels remained over fifty percent. ${ }^{39}$ Russian government officials must have been aware of the region's financial situation, and thus could have chosen to take advantage of it by creating even more weakness through gratuitous destruction and engendering dependence on Russian aid for rebuilding purposes. The need for funding would have been a powerful incentive to give up hope of independence, as otherwise, the Chechens would have simply seceded to a pile of rubble, hopeless to rebuild. The challenges of nation-building in post-conflict societies are great enough without having to physically rebuild a country from the ground up. It is entirely plausible that if the Chechens had succeeded in their quest for independence, the devastation wrought by the Russian attacks would have forced them back to Moscow shortly after independence because the financial strain of nation-building would be too large a barrier to overcome.

This argument, while logically plausible, currently suffers from a lack of supporting evidence. The evidence presented in support of this hypothesis could be used to support my other hypotheses, or could simply be written off as tallies of the destruction wrought as a side 
effect of a brutal military campaign carried out for the aforementioned normative and strategic reasons. Unfortunately, it is almost impossible to discern whether this desire motivated the Russian military based on the available evidence. Therefore, this hypothesis remains only theoretically plausible until such time as it can be either confirmed or denied. Nonetheless, I offer it as a potential alternative or supplement to my main normative and strategic hypotheses, supported by the circumstantial evidence offered above.

\section{Conclusion}

The Russian attack on Chechnya from 1999-2000 was horrific. It left between 8,606 and 17,377 people dead, making it the two deadliest years of the entire conflict. It destroyed infrastructure, families, and an entire region. As former president Mikhail Gorbachev stated, "there were many guilty parties in this war, and history will put everything in its place. But the human lives lost cannot be brought back, and the destruction is difficult to reverse." This paper has put forth three potential motivations for Russia's violence in Chechnya: Putin's desire to restore the reputation of Russia, prevent other groups in Russia from considering secession, and further his own political career; the Russian government's desire to find an effective way of combating the insurgent movement given their limited military capacity; and finally the Russian military's desire to devastate Chechnya so that the rebels had reduced incentives to secede, given that their territory would be irreparably damaged. While this paper points to the normative, reputation-enhancing aspect of the extreme violence, it also implicates the second and third factors as contributing to the decision to use overwhelming force.

The odds, both circumstantial and strategic, were against the Chechen civilians. Because of the situation in which history and politics had placed them, over 17,000 Chechens lost their lives. In the end, Russia superficially achieved its stated goal of silencing the insurgency. However, in actuality, the rebellion lives on in the present movement to unite the Caucuses. While it is too late to save Chechnya from destruction, it is not too late for the international community and domestic political actors to understand the context historical events and the motivations of the Russian government. Learning from Chechnya's horror, the international community can reduce the amount of regions and groups that will have to experience such campaigns of destruction brought upon them by the government. With luck, international actors can fashion a world in which innocent civilians will no longer experience what it is like to struggle to live in and sometimes die in "a small corner of Hell."

\section{Bibliography}

Anna Politkovskaya, "A Small Corner of Hell: Dispatches from Chechnya" (Chicago: University of Chicago Press, 2003).

Alkha Tosuyev, "Russians Push to Chechen Capital", Reuters, October 27, 1999.

Barbara Walter "Reputation and Civil War: Why Separatist Conflicts are so Violent" (New York: Cambridge University Press, 2009).

BBC, "Russia Promise on Chechnya Aid", January 282000.

Benjamin Valentino, Final Solutions: Mass Killing and Genocide in the $20^{\text {th }}$ Century (Cornell University Press, 2004).

Commission on Security and Cooperation in Europe, "Hearing on Chechnya" (Washington DC: US Government Printing Office, 1995).

Debidatta Mahapatra and Seema Shekhawat, "Conflict in Kashmir and Chechnya: Political and Humanitarian Dimensions" (Lancer's Books, 2007).

Derek Chollet and James Goldgeier, "America Between the Wars: From 11/9 to 9/11" (New York: 
Council on Foreign Relations, 2008).

Jamie Walker, "Putin's Bloody Stepping Stone" The Australian, December 11, 1999.

Jason Lyall, "Does Indiscriminate Violence Incite Insurgent Attacks?" in The Journal of Conflict Resolution vol. 53 no. 3 (June 2009), 331-362.

Levada Center - Russia Votes Project, "International Security - Trends", updated on 01 March 2012, accessed on April 24 2012. http://www.russiavotes.org//security/security_trends.php\#476

Michael Coffy, "Military Learning Between the Chechen Wars" in Vestnick: The Journal of Russian and Asian Studies (2006).

Minorities at Risk, "'Data", published December 31 2006, accessed April 24 2012. http://www. cidcm.umd.edu/mar/assessments.asp?regionld=2

Monica Toft, "Indivisible Territory, Geographic Concentration, and Ethnic War" in Security Studies vol. 12 no. 2 (winter 2002/2003).

Nikolai Topuria, "Russia Opens Offensive in Dagestan, Warns of Strikes Agaisnt Chechnya”, Agence France-Presse, August 131999.

Rupert Wingfield-Hayes, "Chechen Problem Far From Over", BBC Moscow, April 62009.

"Russia's Yeltsin Resigns, Names Prime Minister Putin Acting President" in Dow Jones Business News, December 311999.

Stathis N. Kalyvas, "Wanton and Senseless? The Logic of Massacres in Algeria", Rationality and Society vol. 11 no. 3 (1999), 243-285.

Svetlana Gannushkina, ed. "On the Situation of Residents in Chechnya in the Russian Federation: June 2003-May 2004" (Moscow: Memorial Human Rights Watch Center, 2004).

Thomas Smith, "The New Law of War: Legitimizing Hi-Tech and Infrastructural Violence", International Studies Quarterly, vol. 46 no. 3 (2002), 355-374.

Thornike Gordadze, "Chechnya: Eradication of the Enemy Within" in In the Shadow of Just Wars: Violence, Politics and Humanitarian Action (Cornell University Press, 2004).

Upsalla Conflict Data Program, "Russia”, accessed March 1 2012. http://www.ucdp.uu.se/ gpdatabase/gpcountry.php?id=132\&regionSelect=9-Eastern_Europe\#

US Country Report on Human Rights, Russia, 1999, US Department of State.

US Country Report on Human Rights, Russia, 2000, US Department of State.

Valery Tishkov, "Chechnya: Life in a War-Torn Society”, (Berkley: University of California Press, 2004).

“Warplanes Carry out 150 Sorties in Chechnya in Past 24 Hours", Interfax, October 28, 1999.

\section{Endnotes}

1 Stathis N. Kalyvas, "Wanton and Senseless? The Logic of Massacres in Algeria”, Rationality and Society vol. 11 no. 3 (1999), 243-285.

2 Commission on Security and Cooperation in Europe, "Hearing on Chechnya” (Washington DC: US Government Printing Office, 1995).

3 Anna Politkovskaya, "A Small Corner of Hell: Dispatches from Chechnya”, (Chicago: University of Chicago Press, 2003).

4 Upsalla Conflict Data Program, "Russia”, accessed March 1 2012. http://www.ucdp.uu.se/gpdatabase/gpcountry.

php?id=132\&regionSelect=9-Eastern_Europe\# 
5 Anna Politkovskaya, "A Small Corner of Hell: Dispatches from Chechnya".

6 Upsalla Conflict Data Program, “Russia”, accessed March 12012.

7 Jason Lyall, "Does Indiscriminate Violence Incite Insurgent Attacks?" in The Journal of Conflict Resolution vol. 53 no. 3 (June 2009), 339.

8 US Country Report on Human Rights, Russia, 1999, US Department of State.

9 US Country Report on Human Rights, Russia, 1999, US Department of State. Note that the figure of 116 deaths was quoted by the Chechen government, which had incentive to over-represent the number of casualties in the offensive.

10 “Warplanes Carry out 150 Sorties in Chechnya in Past 24 Hours”, Interfax, October 28, 1999.

11 US Country Report on Human Rights, Russia, 1999, US Department of State.

12 US Country Report on Human Rights, Russia, 2000, US Department of State.

13 Thornike Gordadze, "Chechnya: Eradication of the Enemy Within" in In the Shadow of Just Wars: Violence, Politics and Humanitarian Action ,(Cornell University Press, 2004), 189.

14 Debidatta Mahapatra and Seema Shekhawat, "Conflict in Kashmir and Chechnya: Political and Humanitarian Dimensions" (Lancer's Books, 2007), 70-71.

15 "Russia's Yeltsin Resigns, Names Prime Minister Putin Acting President" in Dow Jones Business News, December 31 1999.

16 Thornike Gordadze, “Chechnya: Eradication of the Enemy Within”, 184.

17 Barbara Walter "Reputation and Civil War: Why Separatist Conflicts are so Violent" (New York: Cambridge University Press, 2009), 8-9.

18 Monica Toft, "Indivisible Territory, Geographic Concentration, and Ethnic War" in Security Studies vol. 12 no. 2 (winter 2002/2003), 84.

19 Barbara Walter "Reputation and Civil War: Why Separatist Conflicts are so Violent" 22.

20 Minorities at Risk, "'Data", published 31 December 2006, accessed April 24 2012. http://www.cidcm.umd.edu/mar/assessments.asp?regionld=2

21 Barbara Walter "Reputation and Civil War: Why Separatist Conflicts are so Violent" 26.

23 Benjamin Valentino, Final Solutions: Mass Killing and Genocide in the $20^{\text {th }}$ Century (Cornell University Press, 2004$), 2$.

24 Jamie Walker, “Putin's Bloody Stepping Stone” The Australian, December 11, 1999.

25 Levada Center - Russia Votes Project, "International Security - Trends", updated on March 1 2012, accessed on April 24 2012. http://www.russiavotes.org//security/security_trends.php\#476

26 Derek Chollet and James Goldgeier, "America Between the Wars: From 11/9 to 9/11" (New York: Council on Foreign Relations, 2008), 232.

27 Benjamin Valentino, “Final Solutions: Mass Killing and Genocide in the Twentieth Century” 5.

$28 \mathrm{lbid}$

29 lbid., 82. 
30 lbid., 233.

31 Jason Lyall, “Does Indiscriminate Violence Incite Insurgent Attacks?: Evidence from Chechnya” in Journal of Conflict Resolution vol. 53 no. 3 (June 2009): 357.

32 Alkha Tosuyev, “Russians Push to Chechen Capital”, Reuters, October 27, 1999.

33 Nikolai Topuria, "Russia Opens Offensive in Dagestan, Warns of Strikes Agaisnt Chechnya”, Agence France-Presse, August 131999.

34 Michael Coffy, "Military Learning Between the Chechen Wars" in Vestnick: The Journal of Russian and Asian Studies (2006). Note: taken from a masters-level work.

35 Valery Tishkov, "Chechnya: Life in a War-Torn Society”, (Berkley: University of California Press, 2004$), 188$.

36 Rupert Wingfield-Hayes, “Chechen Problem Far From Over”, BBC Moscow, April 62009.

37 BBC, "Russia Promise on Chechnya Aid", January 282000.

38 Rupert Wingfield-Hayes, "Chechen Problem Far From Over”, BBC Moscow, April 62009.

39 Rupert Wingfield-Hayes, “Chechen Problem Far From Over”, BBC Moscow, April 62009.

Photo Credits: Wikimedia Commons 